\title{
Trauma and emergency: is the unified health system (SUS) the solution in Brazil?
}

\section{Trauma e emergência: o SUS é a solução no Brasil?}

\author{
Gustavo Pereira Fraga ${ }^{1}$, Mario luiz Quintas², Simone de Campos Vieira AbiB ${ }^{3}$
}

Ther he health system in Brazil currently faces a serious crisis. Since the creation of the Unified Health System (SUS) with the Federal Constitution in 1988 (the equivalent of public health systems in other countries), health has become a right for all and a duty of the state, with SUS becoming one of the largest public health systems in the world. Currently it is estimated that SUS serves approximately $75 \%$ of a population of almost 200 million Brazilians ${ }^{1}$. The underfunding of this public system, the high cost of advances in medicine, the difficulty of retaining health professionals in small and distant towns, and the abandonment of hospitals and health facilities, often due to the diversion of resources in a country contaminated by corruption, all mean that health care provision is a serious problem in our midst. This is most evident in the area of emergencies, with overcrowded first aid centers, few diagnostic and therapeutic resources, lack of inpatient beds, inadequately trained medical teams, for both pre-hospital and in-hospital care, among many others problems².

In 2013 the Brazilian population took to the streets in protest against the rising cost of public transport, demanding improvements in education and health, and questioning the hosting of the World Cup in Brazil, a private event that was consuming many resources from within an already deprived public sector. The magic solution for health, as presented by the Federal Government, was the launching of the "More Doctors Program" on July 8, 2013, with the aim of meeting the doctor shortage in rural cities and on the outskirts of large cities ${ }^{3}$. This program is being questioned by the vast majority of medical academies and societies, because it lets foreign doctors exercise medicine in Brazil without first being evaluated by the "National Examination of Diploma Revalidation". The government's objective is to increase the number of physicians in Brazil, which currently has a ratio of 2 physicians/1,000 population, and in order to achieve this goal, another policy was also adopted; that of opening more medical schools. Currently Brazil is the second country in the world with the most medical schools, totaling 241, surpassed only by India, whose population is more than 1.2 billion inhabitants ${ }^{4,5}$. A great concern is the quality, not just the quantity. The grand debate generated within the Brazilian doctors' training scheme followed the rapid launch of the new National Curriculum Guidelines for Undergraduate Medicine, which include compulsory internship in the SUS, with primary and emergency care occupying 30\% of the medical intern's training period, which has a minimum of two years duration ${ }^{5}$. There will be compulsory student assessment every two years with a qualifying nature for medical residency programs. Medical schools have until 2018 to implement the changes ${ }^{6}$.

It was from within this troubled scenario that the question, that is the title of this paper, arose, and which is the central theme of the XI Congress of the Brazilian Trauma Society (SBAIT) and the XVI Brazilian Congress of Trauma Leagues (CoLT), held together in Manaus, from the $25^{\text {th }}$ to the $27^{\text {th }}$ of September, 2014. The answer seems obvious - yes, of course, because if trauma is a public health problem in our country, we depend on the SUS to address its consequences. In 2011, almost a million patients were admitted to public hospitals with injuries from external causes $^{7}$. However, we believe that the SUS cannot solve this problem alone and our participation as health professionals and trainers of human resources is essential. There are several initiatives to integrate teaching and service, bringing together education and health, and we surgeons have to participate ${ }^{8}$. Training in Trauma and Emergency begins during graduation, and most newly qualified doctors end up performing shifts in the Emergency Department, and there are difficulties in teaching in this area, such as: practical scenarios; university hospitals without emergency departments; difficulties with school/hospital partnerships; inadequate physical infrastructure to assist and teach; lack of available trained teachers; lack of preceptors and competence teams; high cost of skills labs and mannequins for simulated training. The Brazilian Association of Medical Education (ABEM) is developing the project "Status of the teaching of Emergency Care in undergraduate medicine", and together with the participation of teachers and students from various medical schools, have produced some recommendations: the need for a longitudinal axis for the teaching of Emergency medicine within the undergraduate

1. TCBC, FACS. Division of Trauma Surgery, Department of Surgery, School of Medical Sciences, University of Campinas (Unicamp), Campinas, SP, Brazil; 2. TCBC. General Surgery Division, Department of Surgery, Clinical Hospital, School of Medicine, University of Sao Paulo; 3. TCBC. Department of Operative Techniques and Experimental Surgery, Department of Surgery, Sao Paulo Federal University - Paulista Medicine School (UNIFESP - EPM). 
curriculum; a program focused on First Aid and Basic Life Support within the first two years of the course; inclusion of students in university extension activities/programs focusing on accident prevention; in the third and/or fourth year there should be a basic skills training course, involving traumatic and non-traumatic emergencies, taking examples from emergency immersion courses such as ATLS ${ }^{\circledR}$; practical experience in pre-hospital care (both ground and mobile), in medical regulations and in hospital first-aid care; recognition of Emergency Medicine as a medical specialization for the training of medical residents and future teachers in this area; and the need for a strategy in achieving better appreciation, the training of tutors, a wage policy and the preservation of professionals working in emergency departments ${ }^{9}$. The big challenge remains however, in not allowing these plans to remain on paper, and instead, ensuring they are well and truly implemented. The problem in Brazil is that many very good projects are not properly planned before being implemented and are used for political purposes, or do not leave the drawing board.

Another important aspect is the training of human resources in the field of Trauma and Emergency Surgery, and obviously the best way to do this is through medical residency programs ${ }^{10}$. We know that residency in General Surgery, with a two year duration, doesn't allow for adequate training, and that even with a third year, it is unlikely that this problem will be resolved, since most graduates end up following another surgical specialty. It's already known that performing trauma surgery with only one year of training is also inadequate, and SBAIT is awaiting assent of the Brazilian College of Surgeons (CBC) to increase this program, recognized by the $M E C$, to two years' duration.

The publication, for the third consecutive year, of issue 4 of the CBC magazine, dedicated to Trauma and Emergency Surgery, is a big incentive for surgeons to publish their studies, disseminating their knowledge and research in this area ${ }^{9}$. The articles of this issue range from prevention, alternative education experience through the Trauma Leagues (one legitimately Brazilian initiative), pre-hospital care, trauma registry deployment, new diagnostic methods, increasingly specialized treatments and surgeries and experimental surgeries, showing the advances that are occurring within the country's trauma services. SBAIT is very grateful to the $C B C$ for maintaining their partnership with SBAIT, but at the same time it seeks to create new work initiatives together, in order to improve Trauma and Emergency care in Brazil. The SUS, with much difficulty, is trying to do its part, and we, as medical bodies representing surgeons, must also do our part, in order to avoid being crippled by laws and ordinances which are created without democratic debate and going against our own nation's principles.

\section{REFERENCES}

1. Paim J, Travassos C, Almeida C, Bahia L, Macinko J. The Brazilian health system: history, advances, and challenges. Lancet. 2011;377(9779):1778-97

2. Tallo FS, Abib SCV, Baitello AL, Lopes RD. An evaluation of the professional, social and demographic profile and quality of life of physicians working at the prehospital emergency medical service (SAMU) in Brazil. Clinics. 2014;69 [ahead of print].

3. Presidência da República. Casa Civil. Subchefia para Assuntos Jurídicos. Brasil. Lei $n^{\circ} 12.871$, de 22 de outubro de 2013. Institui o Programa Mais Médicos e dá outras providências. Acesso em: 09 ago 2014. Disponível em: http://www.planalto.gov.br/ccivil_03/ Ato2011-2014/2013/Lei/L12871.htm.

4. Frenk J, Chen L, Bhutta ZA, Cohen J, Crisp N, Evans T, et al. Health professionals for a new century: transforming education to strengthen health systems in an interdependent world. Lancet. 2010;376(9756):1923-58

5. Escolas Médicas do Brasil. Acesso em: 09 ago 2014. Disponível em http://www.escolasmedicas.com.br/.

6. Ministério da Educação. Conselho Nacional de Educação, Câmara de Educação Superior. Diretrizes Curriculares Nacionais do Curso de Graduação em Medicina. Publicado no DOU n 117 , de 23.06.2014, Seção 1, página 08/11. Acesso em: 09 ago 2014 Disponível em: http://portal.mec.gov.br/index.php?option=com_ content\&view $=$ article\&id $=20279 \&$ ltemid $=866$.

7. Mascarenhas MDM. Perfil epidemiológico e tendências da morbidade hospitalar por causas externas no Brasil, 2002-2011 [tese]. Campinas: Universidade Estadual de Campinas, Faculdade de Ciências Médicas; 2014.

8. Dias HS, Lima LD, Teixeira M. The trajectory of the national policy for the reorientation of professional training in health in the Unified Health System (SUS). Cien Saude Colet. 2013;18(6):1613-24.

9. Fraga GP, Pereira Jr GA, Fontes CER. A situação do ensino de urgência e emergência nos cursos de graduação de medicina no Brasil e as recomendações para a matriz curricular. In: Lampert JB, Bicudo AM, editores. Dez anos das Diretrizes Curriculares Nacionais dos cursos de graduação em Medicina. Rio de Janeiro: Associação Brasileira de Educação Médica; 2014.

10. Fraga GP, Collet-Silva FS, Souza HP. Mais cirurgiões, menos trauma. Rev Col Bras Cir. 2013;40(4):267-8. 